\title{
River network saturation concept: factors influencing the balance of biogeochemical supply and demand of river networks
}

\author{
W. M. Wollheim (1) S. Bernal • D. A. Burns • J. A. Czuba • C. T. Driscoll • \\ A. T. Hansen $\cdot$ R. T. Hensley $\cdot$ J. D. Hosen $\cdot$ S. Inamdar $\cdot$ S. S. Kaushal \\ L. E. Koenig - Y. H. Lu - A. Marzadri - P. A. Raymond - D. Scott • \\ R. J. Stewart $\cdot$ P. G. Vidon $\cdot$ E. Wohl
}

Received: 3 November 2017/Accepted: 22 August 2018/Published online: 29 August 2018

(C) Springer Nature Switzerland AG 2018

\begin{abstract}
River networks modify material transfer from land to ocean. Understanding the factors regulating this function for different gaseous, dissolved, and particulate constituents is critical to quantify the local and global effects of climate and land use change. We propose the River Network Saturation (RNS) concept as a generalization of how river network regulation of material fluxes declines with increasing flows due to imbalances between supply and demand at network scales. River networks have a
\end{abstract}

Responsible Editor: Chris D. Evans.

W. M. Wollheim $(\bowtie) \cdot$ L. E. Koenig · R. J. Stewart Department of Natural Resources and Environment, University of New Hampshire, Durham, NH 03824, USA e-mail: wil.wollheim@unh.edu

S. Bernal

Integrative Freshwater Ecology Group, Center for

Advanced Studies of Blanes (CEAB-CSIC), Blanes, Spain

D. A. Burns

NY Water Science Center, U.S. Geological Survey, Troy, NY 12180-8349, USA

J. A. Czuba - D. Scott

Department of Biological Systems Engineering, Virginia Polytechnic Institute and State University, Blacksburg,

VA 24061, USA

\section{T. Driscoll}

Department of Civil and Environmental Engineering, Syracuse University, Syracuse, NY 13244, USA tendency to become saturated (supply $\gg$ demand) under higher flow conditions because supplies increase faster than sink processes. However, the flow thresholds under which saturation occurs depends on a variety of factors, including the inherent process rate for a given constituent and the abundance of lentic waters such as lakes, ponds, reservoirs, and fluvial wetlands within the river network. As supply increases, saturation at network scales is initially limited by previously unmet demand in downstream aquatic ecosystems. The RNS concept describes a general tendency of river network function that can be

\footnotetext{
A. T. Hansen

St Anthony Falls Laboratory, College of Science and

Engineering, University of Minnesota, Minneapolis, MN 55414, USA
}

\author{
A. T. Hansen \\ Department of Ecology, Evolution and Behavior, \\ University of Minnesota, St. Paul, MN 55108, USA \\ R. T. Hensley \\ School of Forest Resources and Conservation, University \\ of Florida, Gainesville, FL 32611, USA \\ J. D. Hosen · P. A. Raymond \\ School of Forestry \& Environmental Studies, Yale \\ University, New Haven, CT 06511, USA \\ S. Inamdar \\ Plant \& Soil Sciences Department, University of \\ Delaware, Newark, DE 19716, USA
}


used to compare the fate of different constituents among river networks. New approaches using nested in situ high-frequency sensors and spatially extensive synoptic techniques offer the potential to test the RNS concept in different settings. Better understanding of when and where river networks saturate for different constituents will allow for the extrapolation of aquatic function to broader spatial scales and therefore provide information on the influence of river function on continental element cycles and help identify policy priorities.

Keywords River network - Saturation - Supply · Demand - Removal - Retention - Flow regime · Fluxes · Sediment · Gases · Dissolved · Sensors · Macrosystems $\cdot$ Modeling

\section{Introduction}

Continental freshwater ecosystems are characterized by physical, chemical, and biological processes that influence the flux of materials from land to ocean. Sediment, nitrogen, phosphorus, carbon, and other constituents can all be retained (temporarily or permanently) or transformed during downstream transport relative to the amount and forms entering from land. This capacity has long been known for some constituents such as sediments and reactive nutrients (Walling 1983; Alexander et al. 2000;

\section{S. S. Kaushal}

Department of Geology, University of Maryland, College Park, MD 20740, USA

Y. H. Lu

Department of Geological Sciences, University of Alabama, Tuscaloosa, AL 35487, USA

\section{A. Marzadri}

Department of Civil, Environmental and Mechanical

Engineering, University of Trento, Trento, Italy

P. G. Vidon

Department of Forest and Natural Resources

Management, The State University of New York College of Environmental Science and Forestry (SUNY-ESF), Syracuse, NY 13210, USA

E. Wohl

Department of Geosciences, Colorado State University, Ft. Collins, CO 80512, USA
Peterson et al. 2001; Rinaldo et al. 2006), but for others such as carbon this phenomenon has become a more recent research focus (Cole et al. 2007). However, the control of constituent fluxes by surface waters is highly variable in time depending on hydrologic conditions (Kirchner et al. 2000; Botter et al. 2005; Doyle 2005; Wollheim et al. 2008; Hall et al. 2009a).

The centrality of hydrology as a control on downstream fluxes is highlighted in the Pulse-Shunt concept recently applied to carbon (Raymond et al. 2016) and more generally applicable to all constituents involved in fluvial transport (Wollheim et al. 2008; Alexander et al. 2009). Hydrology controls the amount of material supplied to surface waters, and under elevated flows (the pulse) this material is transported farther downstream (the shunt) because residence times are insufficient for aquatic processes to attenuate material inputs. That which is not shunted is retained, removed, or transformed into another form, which may at some later time also be shunted further downstream, i.e. the stream spiraling concept (Webster and Patten 1979; Newbold et al. 1981).

The capacity of river networks (the full complement of tributaries and the main stem river that defines the basin) to regulate fluxes across flow conditions is also determined by the magnitude of the processes that control removal, retention, or transformation along entire flow paths, henceforth referred to as demand. The balance between the supply of a particular constituent to a river network and the demand for that constituent throughout the river network determines net export to the river mouth. Demand can include biological, chemical, and physical processes. All aquatic demand processes can be defined by a net reaction rate, as either a per time constant $\left(\operatorname{time}^{-1}\right)$, a settling/piston/uptake velocity (length time ${ }^{-1}$ ), or an areal or volumetric rate (e.g. mass length ${ }^{-2}$ time $^{-1}$ ) (Boyer et al. 2006; Ensign and Doyle 2006). Reaction rates of demand processes vary over orders of magnitude depending on the constituent, from very high (sediments, ammonium, phosphate, simple sugars), to moderate (nitrate, fresh leaf leachate), to low (non-reactive component of DOC, chloride) (Table 1). The interaction of net reaction rates and hydrologic conditions control the proportion of incoming flux transported further downstream. To understand river network capacity to regulate fluxes requires consideration of the interactions of supply and demand at the 
Table 1 Reaction rates for different constituents in surface waters

\begin{tabular}{lll}
\hline Constituent & $v_{\mathrm{f}}\left(\mathrm{m} \mathrm{year}{ }^{-1}\right)$ & Source \\
\hline Chloride & 0 & Assumption \\
Ammonium & $1200-5500^{\mathrm{a}}$ & Ensign and Doyle (2006) \\
Phosphate & $470-3150^{\mathrm{a}}$ & Ensign and Doyle (2006) \\
Nitrate-total (using solutes) & $260-2300^{\mathrm{a}}$ & Ensign and Doyle (2006) \\
Nitrate-total (using $\left.{ }^{15} \mathrm{~N}\right)$ & $109-977^{\mathrm{b}}$ & Mulholland et al. (2008) \\
Nitrate-denitrification (using $\left.{ }^{15} \mathrm{~N}\right)$ & $9-61^{\mathrm{b}}$ & Mulholland et al. (2008) \\
Dissolved organic carbon & & Mineau et al. (2016) \\
$\quad$ Simple compounds & $90-15,000^{\mathrm{c}}$ & Mineau et al. (2016) \\
$\quad$ Leaf leachates & $1-3700^{\mathrm{c}}$ & Wollheim et al. (2015) \\
$\quad$ Bulk (summer low flow) & $4-37$ & Cheng (1997) \\
Particles & $18-93,000^{*}$ & Ferguson and Church (2004) \\
Sands & $>150,000^{*}$ & Drummond et al. (2015) \\
Bacteria (E. coli) & $40-300$ & Raymond et al. (2012) \\
Gases & $37-37,000$ & \\
\hline
\end{tabular}

All uptake velocities are standardized to units of meters per year to facilitate comparison among different constituents

${ }^{a}$ Interquartile range based on between 139 and 194 studies summarized in Table 2 of Ensign and Doyle (2006)

b Interquartile range based 72 streams across biomes (Mullholland et al. 2008)

${ }^{\mathrm{c}}$ Total range, based on between 22 and 79 studies reported in Table 1 of Mineau et al. (2016)

*Quiescent water

river network scale, integrating across the many smaller streams that hierarchically combine to form larger streams and rivers within a watershed. A general theory of the capacity of river networks to influence constituent fluxes has not previously been explored.

In forest ecosystems, the Nitrogen (N) Saturation hypothesis demonstrated how forests influence rates of $\mathrm{N}$ leaching (Aber et al. 1989). The forest N Saturation hypothesis suggested that $\mathrm{N}$-limited forests leach little $\mathrm{N}$ until deposition increases to sufficient levels and/or demand for growth diminishes, at which point inputs exceed net forest demand and leaching accelerates. Lovett and Goodale (2011) placed the forest $\mathrm{N}$ Saturation hypothesis in a mass balance context as the balance between supply and demand. Forests retain the vast proportion of $\mathrm{N}$ entering the system via atmospheric deposition when $\mathrm{N}$ deposition is low (supply $\ll$ demand) or when forests are in early stages of regrowth (demand $\gg$ supply). As $\mathrm{N}$ deposition increases, or net demand decreases as forests mature, they pass through various stages until supply $\gg$ demand, and the forest is saturated. The saturation concept has not been previously applied in a river network context.
Here we present the River Network Saturation (RNS) concept to explain the capacity of river networks to regulate constituent exports. The RNS integrates the dynamics of supply and demand at the river network scale, building on previous conceptual work such as the Pulse Shunt concept, the Stream Spiraling concept, and the forest N Saturation hypothesis. River network-scale saturation is defined as the condition when the supply of a constituent overwhelms the demand (broadly defined) for that constituent, resulting in loss of the ability of a river network to control the amount exported at the watershed mouth. We suggest the RNS concept applies across form-particulate, dissolved, or gaseous—and across constituent—sediment, pathogens, nutrients, organic matter or inorganic carbon and other constituents. We further suggest that the RNS concept elucidates the emergent functional behavior of whole river networks across space and time.

The goals of this paper are to (1) describe how river networks become saturated based on the balance between demand (= cumulative processes) and terrestrial/landscape supply at network scales; (2) use simple models to explore factors that influence river 


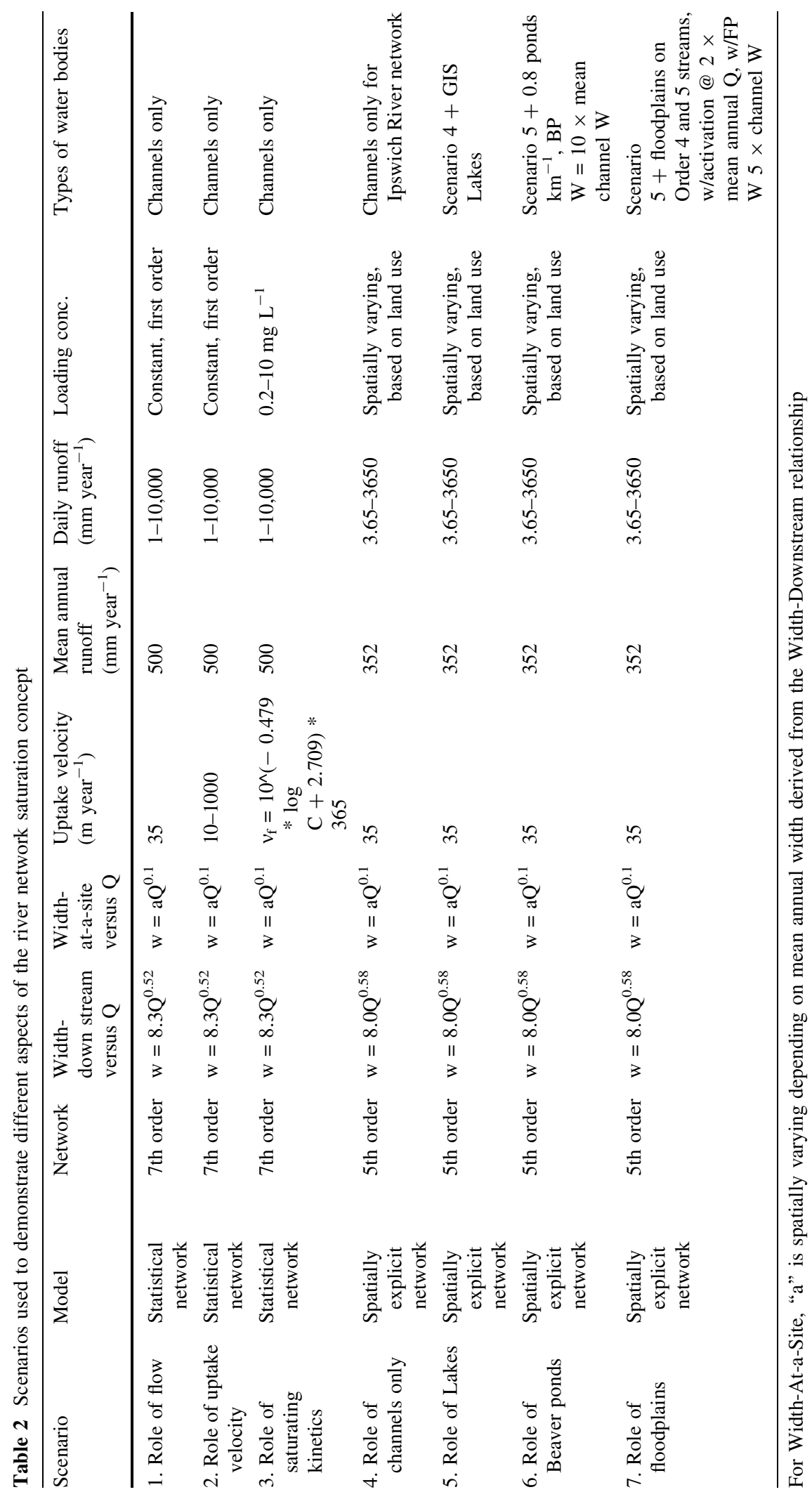


network saturation; and (3) discuss potential approaches for validation of network scale demand for different constituents across flow conditions. A major issue for broad macro-scale questions regarding aquatic function is how to test predictions at the scale of entire river networks. At network scales it is difficult to characterize loading due to the vast number of supply points (e.g. a large number of small streams) and considerable variability over time. Further, the effects of aquatic processes accumulate along the entire flow path, and their sink strength may also fluctuate in space and time, making measurements of network scale removal difficult. Fortunately, a new generation of in situ, high-frequency sensors is becoming more affordable and widely deployed, offering the potential for empirical characterization of the temporal variability of both supply and demand within and across watersheds (Rode et al. 2016; Pellerin et al. 2016; Miller et al. 2016). We will demonstrate how such tools can be used to test the RNS concept.

\section{River network saturation: the balance between supply and demand at network scales}

The River Network Saturation (RNS) concept states that the capacity of a river network to retain, remove, or transform a constituent entering from terrestrial ecosystems declines with increasing flow due to increasing imbalances between supply and demand for a constituent (Fig. 1a). Because flows are variable, river network saturation is highly dynamic over shorter time scales, in contrast to forest saturation which emerges over longer time scales. The flow condition at which river network saturation occurs is also a function of the reactivity of the constituent and characteristics of the river network that affect demand. To illustrate the RNS concept, we assume supply is spatially uniform (i.e. every patch of the landscape contributes a similar areal loading regardless of location in the watershed), and that internal aquatic sources are minimal, as in previous river network studies (Alexander et al. 2000; Helton et al. 2011; Wollheim et al. 2006). Further, we assume that reaction rates for demand processes remain constant throughout the river network and are not affected by flow conditions. Although a reasonable first approximation (Ensign and Doyle 2006), this simplified condition may not be realized in actual river networks.

At the network scale, the proportion of a constituent shunted (= exported) for a given flow condition is determined by cumulative supply and demand curves for the entire river network (Fig. 1a). Once demand remains flat with increasing supply, or changes much more slowly than supply, the river network is considered saturated (i.e. internal demand no longer controls export fluxes). As flows increase, both supply and demand for reactive constituents also increase at network scales, but supply tends to increases more quickly than demand. The proportion of a constituent that is shunted increases rapidly once the river network becomes saturated. These dynamics translate to a higher percent removal of a constituent at low flows (possibly approaching 100\%), and declining removal with increasing flow (Fig. 1b).

The influence of aquatic processes on the amount of constituent transport downstream in an individual water body is defined by the following equation, commonly used in aquatic models (Boyer et al. 2006), which clearly identifies the balance between supply and demand (Wollheim et al. 2008; Wollheim 2016):

$R=1-\exp \left(-\frac{U W L}{Q C}\right)=1-\exp \left(-\frac{\text { demand }}{\text { supply }}\right)$

where $\mathrm{R}$ is the proportion of a constituent removed by a water body (unitless), $\mathrm{U}$ is areal process rate (mass length $^{-2}$ time $^{-1}$ ), $\mathrm{W}$ is mean channel width (length), $\mathrm{L}$ is longitudinal reach length (length), Q is discharge (length $^{3}$ time $^{-1}$ ), and $\mathrm{C}$ is constituent concentration (mass length $^{-3}$ ). In a lake or other lotic water body, WL in Eq. 1 can be replaced with surface area. If processes within the water column dominate, then the numerator in Eq. 1 becomes (UDWL) where $U$ is instead a volumetric process rate (mass length ${ }^{-3}$ time ${ }^{-1}$ ), and $\mathrm{D}$ is depth (length). The numerator represents the demand for the constituent, whereas the denominator represents the supply. The ratio of demand/supply is also equivalent to the Damköhler number (Gu et al. 2007).

For modeling purposes, U/C in Eq. 1 is often represented as the uptake velocity, $v_{\mathrm{f}}$ (length time ${ }^{-1}$; $v_{\mathrm{f}}=\mathrm{U} / \mathrm{C}$ ) because this parameter allows uptake to vary with constituent concentration under the assumption that removal rate is a first order reaction (an 


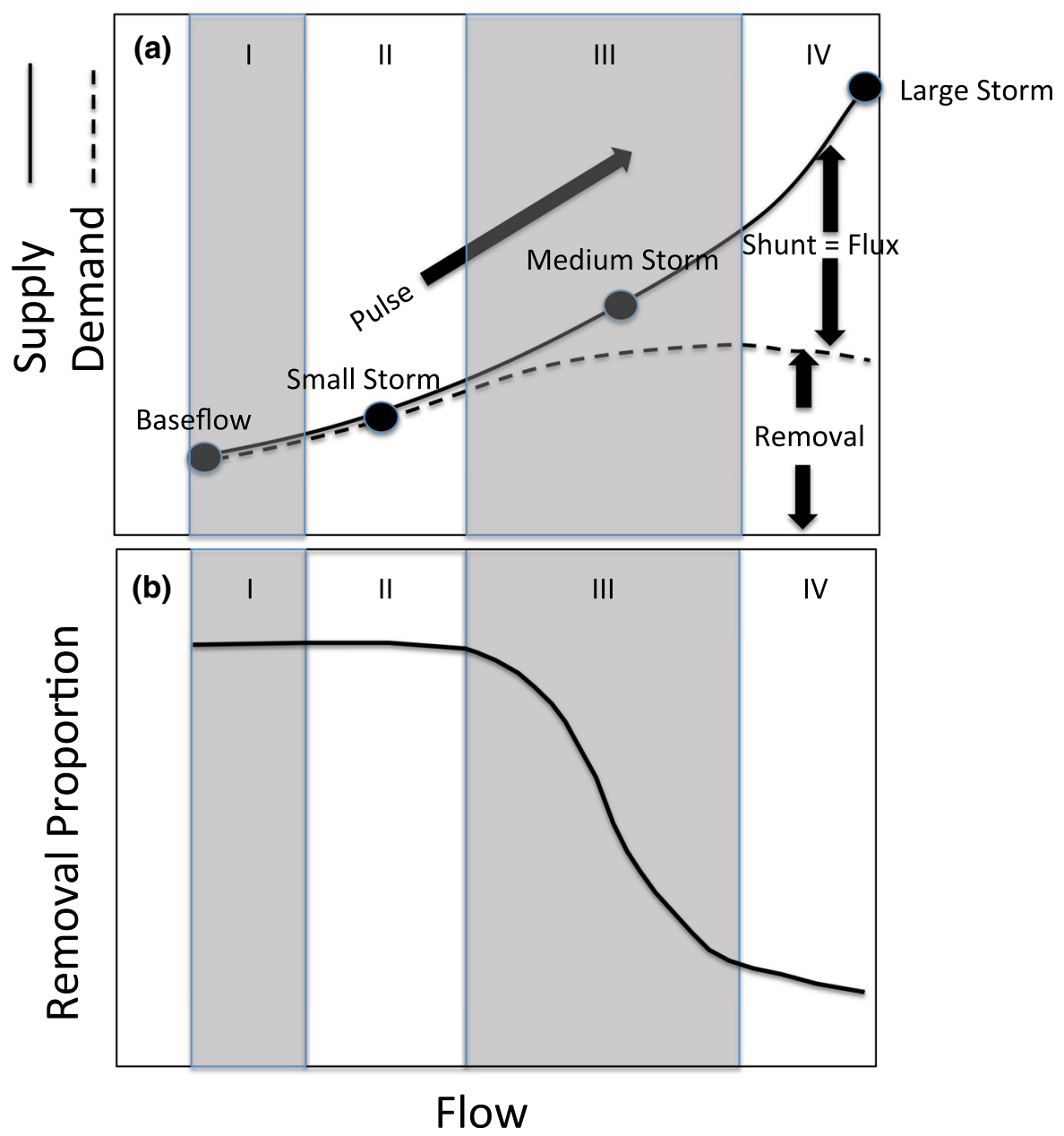

Fig. 1 The River Network Saturation concept, showing a the change in cumulative supply and demand across a range of flow conditions, and $\mathbf{b}$ the resulting shape of network scale removal proportions. Four stages are identified, including Stage 1: when constituent demand by the network is so high that removal occurs immediately at point of entry and there is little networkscale export; Stage 2: when constituents begin to be transported further downstream but demand by previously source limited ecosystems downstream continues to remove most network-

assumption not always met in real systems, and addressed further below, e.g., Mulholland et al. 2008). Uptake velocity (often applied to dissolved constituents) is equivalent to a settling velocity (applied to particles), or piston velocity (applied to gases), and assumes that processes occur at interfaces, which is the case for many aquatic processes including particle settling, sorption, gas evasion, photo-degradation, and processes that predominantly occur in benthic sediments such as assimilation, denitrification or microbial respiration (Table 1). scale inputs; Stage 3: when demand increases at a much slower rate than supply; Stage 4: when demand by the network is small relative to supply. Network scale demand is shown to decline slightly during large storms, but the shape of this curve could vary depending on network responses, e.g. increasing demand if floodplains become connected, decreasing demand if disturbances reduce biological activity, or constant demand if all demand processes are saturated

Aquatic ecosystems have differing demand (or more generally, loss, transformation or processing potential) for various constituents. Examples of major processes include: assimilatory uptake $\left(\mathrm{NH}_{4}{ }^{+}, \mathrm{NO}_{3}{ }^{-}\right.$, orthophosphate), dissimilatory uptake (denitrification of $\mathrm{NO}_{3}{ }^{-}$), microbial oxidation (nitrification of $\mathrm{NH}_{4}{ }^{+}$, DOC), photo-degradation (photo-reactive DOC), sorption (orthophosphate, organic matter), sedimentation (TSS, particulate organic matter), precipitation (dissolved minerals), and gas exchange $\left(\mathrm{O}_{2}, \mathrm{CO}_{2}\right.$, $\mathrm{CH}_{4}, \mathrm{~N}_{2} \mathrm{O}$ ). Some of these processes transform one 
constituent to another $\left(\mathrm{NH}_{4}{ }^{+}\right.$to $\mathrm{NO}_{3}{ }^{-}$, DOC to $\left.\mathrm{CO}_{2}\right)$, or are temporary (TSS deposited in rivers at low flows that is resuspended under high flows; assimilation of nutrients that are eventually remineralized; dissolution of precipitates). Some processes result in permanent removal, such as denitrification, microbial and photochemical oxidation of DOC, gas exchange, or sediment burial in lakes. Here we focus on processes that result in permanent removal (or periods of net uptake). However, we also suggest that the RNS conceptual framework is applicable for temporary storage with remobilization considered as an additional internal supply.

The RNS concept applies Eq. 1 to individual water bodies (stream and river reaches, lakes, ponds, etc.) throughout the river network, which are linked by flows. Upstream demand affects downstream supply. Individual stream or river reaches are typically dominated by throughputs as opposed to internal cycling or removal especially at moderate to high flows (supply $\gg$ demand), whereas many individual lakes and most terrestrial systems are dominated by internal cycling over throughputs (Essington and Carpenter 2001). However, at the scale of river networks, even without ponded waters, supply and demand can be more balanced because most biogeochemical inputs occur in the headwaters (Alexander et al. 2007), and surface water flow paths interact with considerable surface area where processes occur enroute to the basin mouth. The RNS seeks to understand when supply and demand are not balanced at network scales.

Supply of a given constituent to river networks generally increases with increasing discharge $(\mathrm{Q} * \mathrm{C}$ in Eq. 1). C may either increase or decrease during flow events (Evans and Davies 1998). Some constituents are transport limited, with $\mathrm{C}$ increasing with discharge (e.g. DOC: Raymond and Saiers 2010; POC and TSS: Dhillon and Inamdar 2014), so the rate of increase in the constituent load (= supply) will be greater than the increase in discharge (supply is concave up vs. discharge, as in Fig. 1). Other constituents are source limited, with $\mathrm{C}$ typically diluting with increasing discharge (e.g. cations: Godsey et al. 2009, geogenically derived SRP: Hensley et al. 2017; nitrate in urban and agricultural areas: $\mathrm{Hu}$ et al. 2017; Koenig et al. 2018), but even under these conditions, supply increases rapidly because dilution rarely offsets the discharge increase (i.e. flux is dominated by Q term; Godsey et al. 2009; Basu et al. 2010; Thompson et al. 2011).

The distribution of water and constituent supply from the landscape in a river network context is skewed towards smaller streams, assuming spatially uniform areal loading of sources throughout the watershed. The total length of streams in a watershed is always dominated by small streams (Leopold and Maddock 1953; Bishop et al. 2008). Small streams intersect most of the landscape, and therefore typically intercept a disproportionately large proportion of constituent inputs from land (Alexander et al. 2007). Some river networks may have more inputs skewed towards river mouths, as for example, when human activities (urban or agricultural) are located along larger rivers (e.g., for N, P, labile organic matter), which would also affect the network-scale balance between supply and demand (Mineau et al. 2015), but is not considered here.

The RNS concept considers how network-scale demand changes relative to supply across flow conditions. The response in demand to changes in flow is determined by three mechanisms that influence the numerator in Eq. 1, manifested as changes in river length, river width, or uptake (here represented as $\mathrm{U} / \mathrm{C}=v_{\mathrm{f}}$ ) as flow increases. Length of headwater streams may increase or decrease depending on wet or dry conditions, especially in areas characterized by intermittent flow regimes (Bernal and Sabater 2012; Bernal et al. 2013). River widths at specific locations increase relatively little with changes in flow when channelized (Leopold and Maddock 1953; Knighton 1998), until bank full thresholds are exceeded and floodplains become connected (which is explored below). Finally, uptake processes may also be affected by flow. For now we assume that $\mathrm{U}$ relative to $\mathrm{C}$ in Eq. $1\left(=v_{f}\right)$ remains constant with changes in $Q$ to more simply demonstrate the underlying function of the river network. In reality, reaction rates vary depending on disturbance, kinetic responses to concentration (zero, first, or higher order), light, temperature, microbial communities, and other factors.

Three types of network scale saturation can occur: capacity saturation, kinetic saturation (Lovett and Goodale 2011), and spatial saturation. Capacity saturation occurs when there is no net demand, so inputs equal outputs. Kinetic saturation occurs when some net demand (removal) occurs but inputs $\gg$ outputs. Spatial saturation is an additional form of saturation 
we introduce in this analysis that emerges at river network scales. Spatial saturation occurs as demand is met in propagating fashion through an entire set of linked ecosystems. At some low level of supply, all of a constituent may be removed near its point of input to the network. Because loading to river networks is delivered predominantly to smaller headwater streams, only a proportion of reactive constituents is transported downstream under low flows. As flow increases, more of the constituent tends to be transported downstream. At low flows, there is unrealized demand in downstream reaches which starts to be met as excess supply is transported from upstream under higher flows. We will demonstrate the concept of spatial saturation and how it is affected by flow, reaction rates, and other factors, such as the presence of lakes and floodplains.

\section{Stages of network-scale saturation response}

Four stages of network-scale constituent removal describe the spatial saturation response of entire river networks (Fig. 1b). These stages are defined by a logistic response curve. Stage 1 is characterized by nearly complete removal at the network scale because demand is so great that constituents are immediately processed as they enter the network. In this stage, most network-scale removal occurs in headwater streams near the initial location of non-point source entry. Potential demand in large rivers is unmet in this stage. Stage 2 continues to show near complete removal at the network scale, but under this condition, demonstrated below, removal by downstream reaches limits leakage from the overall network. At the overall network scale, demand continues to keep pace with supply. Stage 3 is characterized by rapid declines in the proportion of constituent removed, resulting in increased breakthrough and export from the river network as loads continue to increase with a slowing increase of the commensurate demand. In Stage 4, the river network essentially has lost the ability to attenuate additional input fluxes, because supply overwhelms demand. The rate at which different constituents move through these stages (or remain in a particular stage) depends on hydrological and geomorphological conditions, as well as physical or biological processes that influence the constituent.

\section{Demonstration of river network saturation (RNS) concept}

We use two modeling approaches to demonstrate the RNS concept (Table 2). The first is a statistical model based on river network fractal geometry that accounts for hydraulic characteristics and removal by different river orders, the distribution of direct inputs relative to river order (i.e., where terrestrial sources first enter the river network), and the flow path water takes from source to basin mouth (Wollheim et al. 2006; Raymond et al. 2016). This model implements Eq. 1 and is applied to a hypothetical seventh order river network $\left(\sim 5500 \mathrm{~km}^{2}\right)$ to explore how flow conditions, reaction rates, and kinetic assumptions affect river network saturation in channel networks (Scenarios 1-3, Table 2). This approach focuses only on the channel network. The second modeling approach uses the Framework for Aquatic Modeling of the Earth System, a spatially distributed routing model previously applied to channel networks (Wollheim et al. 2008, 2015; Stewart et al. 2011, 2013; Samal et al. 2017), modified to account for the role of lakes/ reservoirs, beaver ponds, and floodplains to heuristically demonstrate how river network saturation is affected by lentic water bodies (Scenarios 4-7, Table 2). The second model approach is fully spatially explicit, based on the conditions in the Ipswich River network, MA ( $\sim 400 \mathrm{~km}^{2}$, Wollheim et al. 2008). We assume chemostatic loading conditions (i.e., loading concentrations remain constant with changing runoff/ flow) and that $v_{\mathrm{f}}$ is not affected by water body type.

For each scenario, we present the response curve of percent of total inputs that are removed by the river network versus flow (as in Fig. 1b). The scenarios include the effects of increasing flow, uptake velocity, concentrations (with kinetic response of uptake velocity), and aquatic habitat (Table 2). In all scenarios except the kinetic response scenario, we assume first order kinetics (i.e. $\mathrm{U}$ increases linearly with $\mathrm{C}$, so $\mathrm{v}_{\mathrm{f}}$ stays constant throughout the network).

\section{River network saturation depends on flow conditions}

As runoff from land increases, supply of a given constituent to the river network increases and demand is eventually overwhelmed so that the percent removal 
by the river network declines. At network scales, the balance between supply and demand changes nonlinearly between low and high flow, resulting in a logistic removal curve. For $v_{\mathrm{f}}$ typical of denitrification during summer (Scenario 1 in Table 2, line for $v_{\mathrm{f}}=35 \mathrm{~m} \mathrm{year}^{-1}$ in Fig. 2), removal of nonpoint inputs to the river network is near $100 \%$ through flows equivalent to about $10 \%$ of the mean annual flow. Percent removal decreases rapidly to $34 \%$ at mean annual flow, and further declines to $<5 \%$ at flows tenfold higher than the mean annual. The lack of responsiveness below a certain flow threshold (Stage 1 and 2 in Fig. 1) indicates excess demand relative to supply at network scales that continues to be met as supply initially increases.

The rapid decline in constituent removal as flows continue to increase (Stage 3) occurs because once downstream demand is met (at the end of Stage 2), network-scale demand changes slowly with further increases in flow, while supply increases rapidly. In channel-only river networks (Scenario 1), habitat area increases slowly with increasing discharge (width vs. $\mathrm{Q}$ at-a-site exponent typically $\sim 0.1$, Table 2 ), while depth and velocity increase rapidly (Leopold and Maddock 1953; Knighton 1998). As a result, all else being equal, demand increases slowly $\left(\sim \mathrm{Q}^{0.1}\right)$ while supply increases rapidly ( $\sim \mathrm{Q}^{1}$ if chemostatic). This pattern is commonly interpreted as the effect of declining residence time, but is here placed in a supply and demand context (note that the terms in Eq. 1 are equivalent to $\mathrm{k} * \tau$, where $\mathrm{k}$ is the per time constant and $\tau$ is residence time; Wollheim 2016). In nature, the rate of decline during Stage 3 may differ

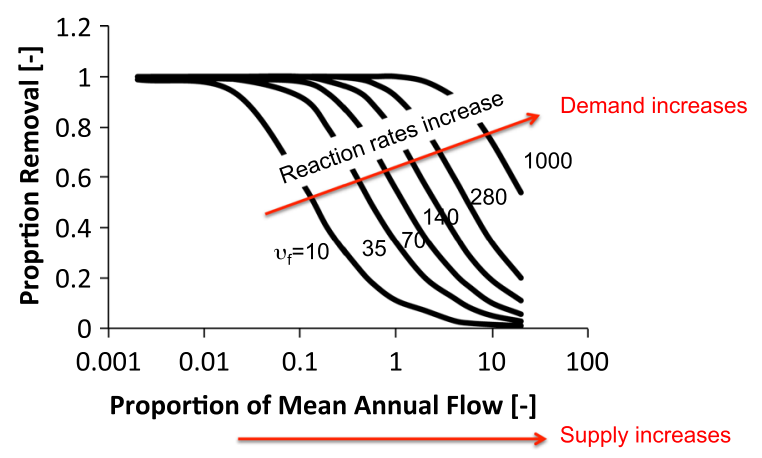

Fig. 2 Network scale removal proportions as a function of flow (proportion of mean annual flow conditions) assuming different constituent reaction rates (Scenarios 1 and 2). $v_{\mathrm{f}}$ in units of $\mathrm{m}_{\text {year }}{ }^{-1}$ from the pattern portrayed in this scenario (assuming channel only) because the model assumes that newly available habitat $\left(\mathrm{w} \sim \mathrm{Q}^{0.1}\right.$ ) has the same reaction rate $\left(\right.$ as $\left.v_{f}\right)$ as the previously inundated area. Yet, this condition may not always be realized (e.g. biota may take time to recolonize previously dried habitat, Sabater et al. 2016). Moreover, process rates may decline in channels following storms, e.g. when depth or turbidity increases, impeding light or scouring biota on the stream bottom, and reducing demand for nutrients (Fisher et al. 1982; Uehlinger 2006). Rate of decline in Stage 3 could also slow if connectivity with floodplains or other reactive ecosystems increases (see below). The RNS concept can be used as a null model to test the importance of these other factors.

\section{River network saturation is initially prevented by downstream systems}

Network-scale saturation does not occur across a range of lower flow conditions (Scenario 1) because large rivers within the network are source-limited at extremely low flows, and can initially process increased leakage from upstream systems as flows increase. Most water and non-point sources enter the network initially in low order streams (dashed line in Fig. 3) (Alexander et al. 2007), so these components of the network are first to potentially process most inputs. In the river network considered in Figs. 2 and 3 , which is constructed using typical geomorphic ratios (drainage area, number, and length ratios, Wollheim et al. 2006), 60\% of direct inputs from the landscape occur to first and second order streams. At low flows ( $<2 \%$ of mean annual flow), supply to these small streams is similar to their demand (even at relatively low reaction rates, $v_{\mathrm{f}}=35 \mathrm{~m}$ year $^{-1}$ ), so very little constituent is exported downstream (2\% line in Fig. 3a). Removal occurs essentially as soon as the constituent enters the network (Fig. 3).

As constituent supply increases with flow, local demand in low order rivers is overwhelmed and a greater proportion is transferred downstream. Assuming that $v_{\mathrm{f}}$ is constant throughout the river network, larger rivers have unmet demand at low flow (Koenig et al. 2017) that is met at higher flows, maintaining high removal proportions at the network scale. Integration under the supply curve (dotted line) and under each removal curve in Fig. 3 indicates the proportional 


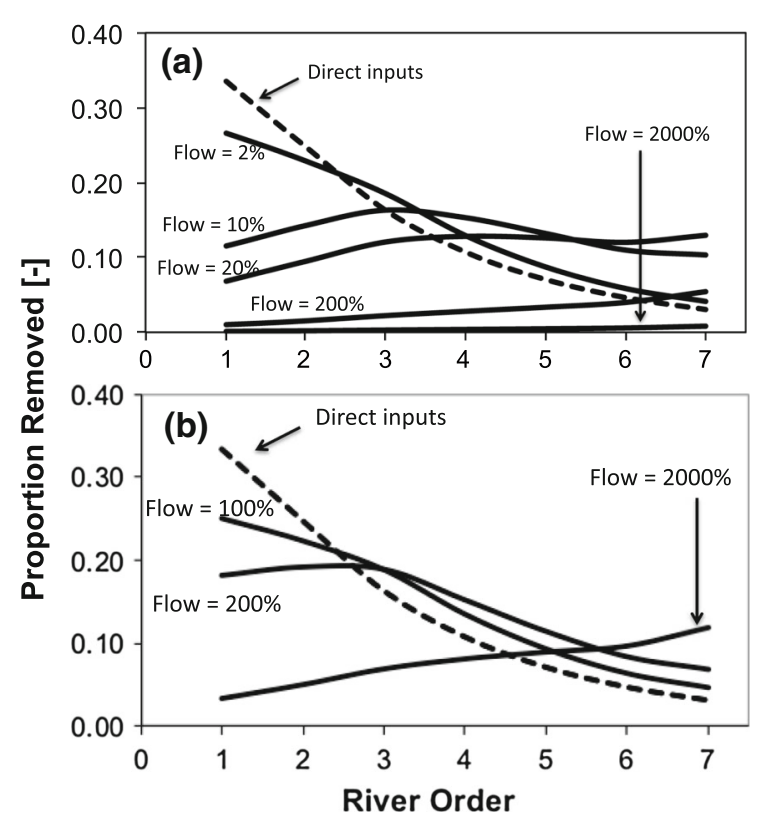

Fig. 3 Distribution of total river network inputs removed by each river order within a 7 th order river network as a function of flow conditions represented as \% of mean annual flow a assuming uptake velocity $=35 \mathrm{~m} \mathrm{year}^{-1}$ and $\mathbf{b}$ assuming uptake velocity $=1000 \mathrm{~m}_{\text {year }}{ }^{-1}$. Dotted line shows distribution of direct non-point inputs where terrestrial sources first enter the river network. Input concentrations are assumed spatially uniform and chemostatic (no change) across flow conditions. The integration under each curve corresponds with the total network removal in Fig. 2 during the particular flow condition

network-scale removal. As Q increases, cumulative removal by 1 st and 2 nd order streams is less than their direct inputs from the landscape, while removal by larger order streams is greater than their direct inputs, because they are removing excess constituent transported from upstream (Fig. 3).

The contribution of intermediate-sized streams to overall network function increases with increasing flows. Over a certain flow range, the contribution of these intermediate streams actually dominates at network scales (Fig. 3a, flow $=10 \%$ of mean annual flow). As flows and associated constituent supplies continue to increase, greater breakthrough from intermediate streams occurs, increasing the role of the largest river segments. At higher flows (flow $>200 \%$ of mean annual flow), network control of flux declines, but the remaining removal capacity is dominated by the largest rivers.

\section{River network saturation depends on uptake velocity}

In Scenario 2, we explore the effect of changes in $v_{\mathrm{f}}$ on the removal capacity of river networks (Table 2). As $v_{f}$ increases across the range of possible values previously observed for different constituents (Table 1), the capacity of the network to remove constituents increases considerably. The higher the $v_{\mathrm{f}}$, the broader the range of flows under which network demand is in Stage 1 and 2. At reaction rates typical for ammonium (assimilation plus nitrification, $v_{\mathrm{f}-}$ $>1000 \mathrm{~m} \mathrm{year}^{-1}$, Ensign and Doyle 2006), network scale removal remains at essentially $100 \%$ through mean annual flow. Even at the highest flow considered (20-fold higher than the mean annual), removal approaches $60 \%$ of inputs. Over most of the flow range, constituent removal is predominately in the low order rivers, but again, at the highest flows large rivers dominate network scale function (Fig. 3b). This pattern is consistent with observations that ammonium is rarely at concentrations much above the analytical detection limits unless located immediately downstream of a pollution source or in proximity to a reducing environment. Other constituents may have very low reaction rates (e.g. chloride which is conservative). Relatively conservative constituents are therefore always in Stage 4, where removal is minimal and thus hydrological export is equivalent to supply. The fate of constituents with different $v_{f}$ values (Table 1) under different flow conditions can be readily assessed using Fig. 2.

\section{River network saturation depends on uptake kinetics}

Under the assumption of first order kinetics, as often invoked in water quality models, the concentration of the constituent itself does not influence removal proportions (the balance between supply and demand) because uptake increases linearly with concentration and reaction rates remain constant. Thus, if supply increases due to increasing concentration (e.g., with land use change), there would be proportionally increasing uptake, and the response curves in Fig. 2 would remain unchanged. However, for some constituents (e.g. $\mathrm{NH}_{4}, \mathrm{NO}_{3}$ ), reaction rates (as $v_{\mathrm{f}}$ ) can be concentration dependent (Mulholland et al. 2008; 
Dodds et al. 2002). In this case, uptake (U, demand) will respond non-linearly to concentration (C, supply) depending on the type of reaction kinetics. Kinetics can be described as saturating (Michaelis-Menten) or efficiency loss (Dodds et al. 2002; O’Brien et al. 2007; Hall et al. 2009b). We can readily model this scenario by considering $v_{\mathrm{f}}$ as a function of concentration (as in Mulholland et al. 2008; Wollheim et al. 2008).

Assuming a scenario with efficiency loss of uptake typical of denitrification (Table 2, Scenario 3), increasing concentration of terrestrial inputs shifts the removal curve versus flow to reduce the capacity of the network to remove nitrate (Fig. 4). The range of flows over which the network retains most of the inputs (Stage 1 and 2) declines, and the range over which the network has little or no influence increases (Stage 4). In effect, under the assumption of concentration-dependent $v_{\mathrm{f}}$ kinetics, increases in supply are exacerbated by a declining capacity of the network to remove the constituent. Further, removal in upstream reaches has the added benefit of enhancing removal efficiency by downstream reaches as $\mathrm{C}$ declines with distance downstream (Mulholland et al. 2008). Thus, higher order water bodies become relatively more important at network scales. Concentration dependence of reaction rates will likely be more important for more biologically reactive nutrients $\left(\mathrm{PO}_{4}{ }^{3-}\right.$, $\mathrm{NH}_{4}{ }^{+}, \mathrm{NO}_{3}{ }^{-}$, reactive DOC) than for other constituents (e.g. TSS).

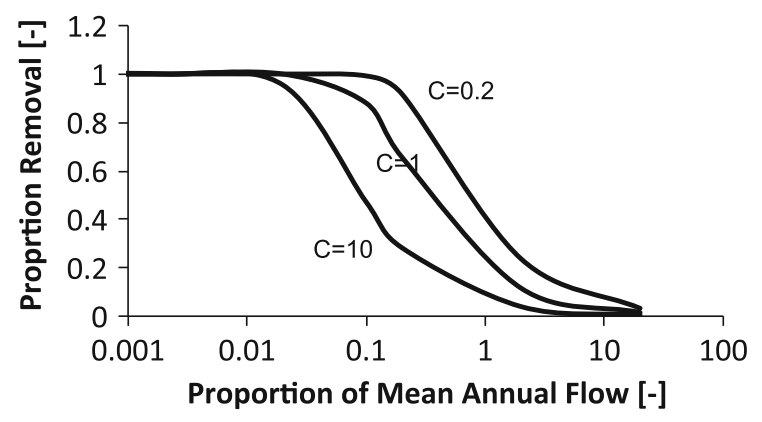

Fig. 4 Network scale nitrate removal proportions as a function of flow (proportion of mean annual flow) for different loading concentration $\left(0.2,1\right.$, and $10 \mathrm{mg} \mathrm{N} \mathrm{L}^{-1}$, Scenario 3), assuming the uptake velocity versus concentration relationship reported in Mulholland et al. (2008) for the 9 sites at the Plum Island LTER in Massachusetts for denitrification of nitrate
River network saturation depends on abundance of lakes, ponds, and wetlands

Actual networks are highly heterogeneous in space and time. In the final set of scenarios, we varied the habitat term in Eq. $1, \mathrm{~W} \times \mathrm{L}$, by incorporating different water bodies into the river network. As noted above, Eq. 1 can be revised for volumetric processes by replacing $U$ with a volumetric uptake, and habitat $=\mathrm{W} \times \mathrm{D} \times \mathrm{L}$. Although some processes become more important in the water column of lentic waters, for simplicity we continue to apply the assumption that processes at horizontal interfaces dominate (benthic, air-water). Fluvial wetlands, ponds, lakes, reservoirs and floodplains all introduce additional removal/transformation capacity. Connectivity of fluvial wetlands and floodplains can vary significantly through time depending on $\mathrm{Q}$, as well as due to human activities (e.g. levees). Thus, this final set of scenarios only demonstrates tendencies.

We ran four scenarios for the Ipswich River watershed in Massachusetts (MA), USA, across a range of flow conditions (Scenarios 4-7, Table 2). Scenario 4 assumes only a channel network, as before (cumulative channel surface area $=1.1 \mathrm{~km}^{2}$ at mean annual flow). Scenario 5 considers lakes/reservoirs as identified by existing GIS layers (surface area $=10.9 \mathrm{~km}^{2}$ ). Lakes replace all river channels within their boundaries, and the lake attribute for surface area $(\mathrm{W} \times \mathrm{L}$ in Eq. 1) determines the removal capacity, assuming their area changes little relative to flow. Scenario 6 considers beaver ponds in addition to lakes and channels (surface area $=0.9 \mathrm{~km}^{2}$ ). Beaver ponds are assumed to occur randomly throughout the network at densities of 0.8 ponds $\mathrm{km}^{-1}$ (PIE LTER unpublished data), with individual surface areas tenfold greater than the mean annual channel width they replace. Finally, Scenario 7 considers the activation of floodplains at twofold the mean annual flow in stream orders 4 and 5, assuming floodplain width is fivefold the channel width (flooded surface area $=3.9 \mathrm{~km}^{2}$ ). In each case, we assume biological activity of the non-channel water body is the same as in river channels (benthic $\mathrm{U} / \mathrm{C}=35 \mathrm{~m}_{\text {year }}{ }^{-1}$ ).

A similar logistic curve occurs for each scenario, but constituent removal is higher across a greater range of flow as additional types of lentic water bodies are considered (Fig. 5). The addition of lakes and beaver ponds modestly increases the range of flows in 
Stage 1 and 2, and decreases the range of flows in Stage 4. At mean annual flows, removal increases from $28 \%$ in Scenario 4 (channels only) to $52 \%$ in Scenario 6 (lakes + beaver ponds). Floodplains in 4 th and 5th order rivers elevate removal proportions at higher flows. Thus, lentic water bodies can add considerable demand and reduce the range of flow at which saturation occurs.

\section{Observations to test RNS concept}

The RNS concept is a simple framework that allows describing and predicting network scale function over time and space, but the predicted patterns need then to be challenged with empirical observations. Observations of flow and concentrations are often collected at basin mouths to test the predictions of river network models parameterized a priori (Wollheim et al. 2008; Alexander et al. 2009). However, such measurements do not isolate the effects of cumulative loading and river network transformation. As high frequency, in situ nutrient sensors become more affordable, the potential arises to deploy them in ways that address network scale function across flow conditions.

One approach to isolate aquatic removal across flow conditions is to deploy a network of nested

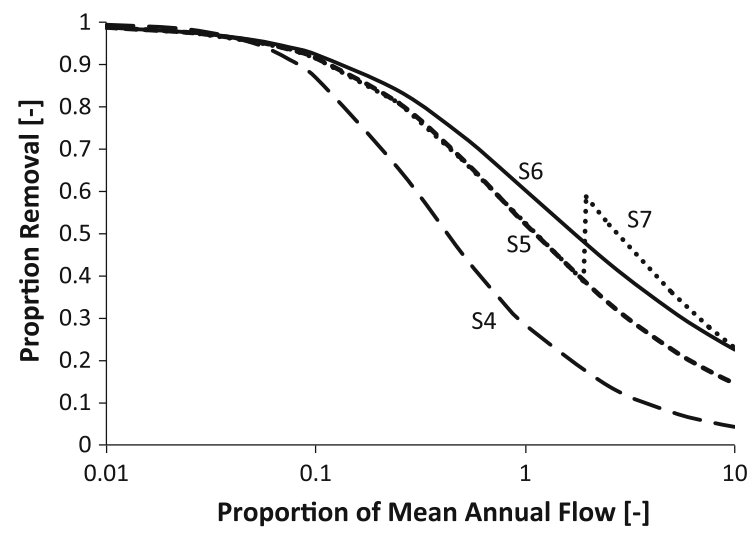

Fig. 5 Network scale removal proportions as a function of flow (proportion of mean annual flow) accounting for different types of aquatic systems in the Ipswich River watershed (Drainage Area $=400 \mathrm{~km}^{2}$ ), containing a 5th order river network. S4 = channel network only; S5 = S4 + GIS lakes; S6 = S5 + beaver ponds at density $0.8 \mathrm{~km}^{-1}$, pond $\mathrm{W}=10 \times$ mean annual channel width; S7 $=$ S5 + flood plain activation at $2 \times$ mean annual flow in 4 th and 5 th order streams where floodplain width is $5 \times$ the mean annual channel width sensors across headwaters to basin mouth of a single watershed. Network removal can then be estimated using an end member mixing analysis using both reactive and conservative constituents (Wollheim et al. 2017). Constituent loads are estimated at storm event scales in multiple headwaters to infer end members of loading versus flow for different land use types. These end members are then used to predict the reactive to conservative flux ratio across flows at the basin mouth assuming conservative mixing. Divergences between observed and predicted reactive to conservative flux ratios indicate network scale retention, which can then be used to test RNS predictions. This approach thus isolates both the loading and network transformation signal at storm event or stable base flow scales. Results would be an independent test of river network model predictions.

To demonstrate this approach, we applied the simple statistical model used in Scenario 1 (Table 2; Wollheim et al. 2006) to a fourth order river network in which Wollheim et al. (2017) deployed the end member sensor approach to examine network scale $\mathrm{NO}_{3}{ }^{-}$retention (the Oyster River watershed, $\mathrm{NH}$, drainage area $=50 \mathrm{~km}^{2}$ ). Model predictions of $\mathrm{NO}_{3}{ }^{-}$ retention across flow conditions indicate a similar overall magnitude as observations and a similar decline with increasing storm size, within the uncertainty of the observations (Fig. 6a). However, the shapes of the curves differ, with observations suggesting that net mobilization of $\mathrm{NO}_{3}{ }^{-}$within the network may occur during the largest storm events. Internal sources are not considered in the simple network model used here. Given the uncertainties in the observations, and simple assumptions in the model, we do not wish to emphasize the model validation per se. Rather, we wish to emphasize the potential for sensor networks, coupled with networkscale modeling, as a tool to better understand the dynamic processes inherent in river networks (Rode et al. 2016).

Another approach for addressing network scale processes involves using spatially distributed synoptic sampling throughout river networks at various snapshots in time. For example, Hansen et al. (2018) measured stream nitrate throughout a $44,000 \mathrm{~km}^{2}$ watershed within the Upper Mississippi River basin during seven separate synoptic sampling events. In that study, measurements collected under moderate to high flow conditions were used together with an 


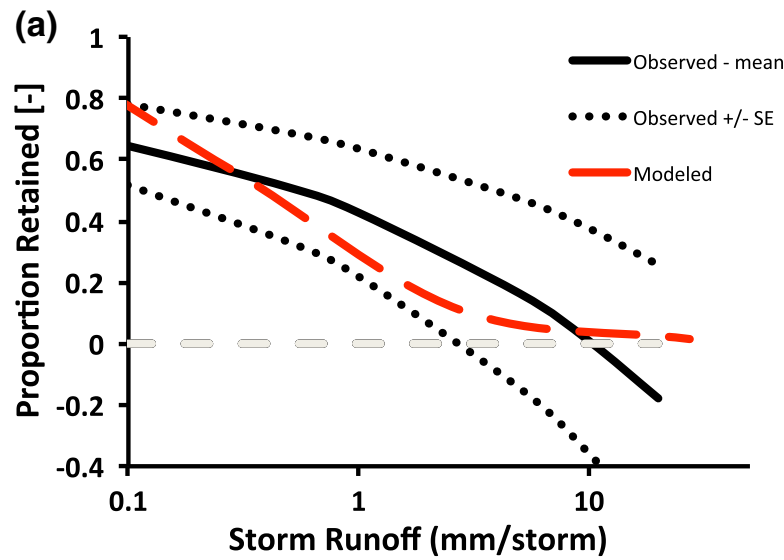

Fig. 6 Empirical estimates of river network scale function as a proportion of nitrate removed by river networks for different storm sizes estimated from nested in situ sensors and an end member mixing analysis applied in the Oyster R. Watershed, $\mathrm{NH}$ (Wollheim et al. 2017) compared to model predictions for this watershed assuming $v_{\mathrm{f}}=35 \mathrm{~m} \mathrm{year}^{-1}$, and $\mathbf{b}$ observed

independently derived process model (Czuba et al. 2018) to reveal that $\mathrm{NO}_{3}{ }^{-}$concentrations decreased as mass travel time increased (Fig. 6b). Most sites with the cumulative travel times greater than $\sim 10 \mathrm{~h}$ (Fig. 6b black markers) had $>8 \%$ lentic waters (Czuba et al. 2018), confirming the potential contribution of ponded waters to network constituent retention (Fig. 5).

\section{Implications of the RNS}

The RNS concept serves as a general framework for better understanding aquatic function at network scales across watershed types and can be used to generate hypotheses and predictions under different conditions and assumptions (Table 3). The RNS demonstrates a general tendency of river network biogeochemical behavior as a function of flow based on network-scale supply and demand. It synthesizes a number of interacting factors, including network structure, hydrology, loading, and aquatic process rates. The core prediction that network scale removal has a tendency to decline in a non-linear pattern with increasing flow should underlie the dynamics across networks. Deviations from this general pattern will be important to identify and assess. Only a few factors have been explored in this analysis. Other potentially

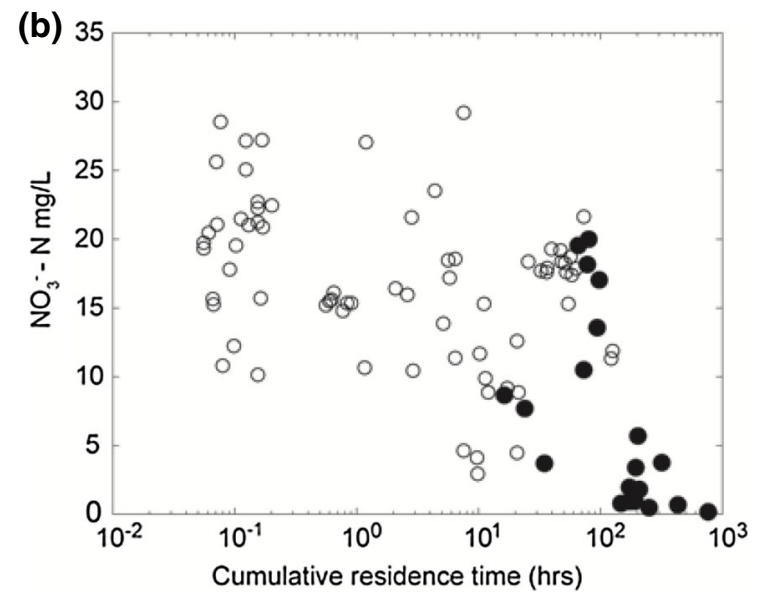

nitrate concentration with increasing cumulative residence time, a metric of time spent in a surface water flow path, in an agricultural basin in the Upper Mississippi during synoptic surveys conducted over three years. Closed points are sites where upstream watershed area contains $>8 \%$ lentic waters

important factors include variation of river network structure, flow regimes, the effect of disturbance, loading distributions (in space and time), seasonality of process rates, internal aquatic sources, role of water column processes, and their interactions. All these factors can differ among watersheds and among biomes (Mineau et al. 2015; Ruegg et al. 2016; Helton et al. 2017; Marcé et al. 2018; Park et al. 2018; Gardner and Doyle 2018).

One of the potential applications of the RNS is to assess how changes caused by human activity, climate change, and climate variability affect river network scale supply, demand, and saturation dynamics across flow conditions. Hypotheses regarding these effects can be constructed using the RNS as a null hypothesis. For example, point source inputs to larger rivers of the network would elevate network-scale supply by a similar amount across flow conditions, while networkscale demand to take advantage of this additional supply increases relatively little because only a small proportion of a network's reactive surface area is downstream. The resulting removal curve (as in Fig. 1) would be shifted lower across flow conditions and if supply is sufficiently high, $\mathrm{R}$ may never approach 1 , even at low flows.

As another example, we can hypothesize that under typical flow conditions, there is a certain response curve (Fig. 1b), but that following disturbances caused 
Table 3 Examples of potential factors influencing supply and demand in different types of river networks, along with hypothesized network scale response

\begin{tabular}{|c|c|c|c|}
\hline System & Impact to supply & Impact to demand & $\begin{array}{l}\text { Hypothesized network-scale } \\
\text { responses }\end{array}$ \\
\hline $\begin{array}{l}\text { Agricultural } \\
\text { networks }\end{array}$ & $\begin{array}{l}\text { C: Increased } \mathrm{NO}_{3} \text { inputs due to } \\
\text { excess fertilizer } \\
\text { Q: Increased peak flows, less base } \\
\text { flow due to tile drainage }\end{array}$ & $\begin{array}{l}\text { L: Increased length due to drainage } \\
\text { ditches or canals } \\
\text { U: Denitrification process saturates; } \\
\text { Source limitation alleviated } \\
\text { throughout network at high flows }\end{array}$ & $\begin{array}{l}\mathrm{N}_{2} \mathrm{O} \text { emissions are highest in smaller } \\
\text { streams at low flows; contribution } \\
\text { of larger streams increases as flows } \\
\text { increase. } \mathrm{NO}_{3} \text { export increases } \\
\text { faster than } \mathrm{N}_{2} \mathrm{O} \text { emissions at } \\
\text { network scale with increasing flow }\end{array}$ \\
\hline $\begin{array}{l}\text { Urban } \\
\text { networks }\end{array}$ & $\begin{array}{l}\text { C: Increased non-point nutrient } \\
\text { inputs; Point sources lead to higher } \\
\text { supply at lower flows } \\
\text { Q: Engineered flow paths lead to } \\
\text { higher storm flow; Reduced } \\
\text { catchment ET leads to higher base } \\
\text { flow, or reduced recharge leads to } \\
\text { less base flow }\end{array}$ & $\begin{array}{l}\text { L*W: Stream burial; Disconnected } \\
\text { floodplains } \\
\text { U: Reduced riparian cover; Less } \\
\text { particulate carbon input/storage but } \\
\text { more bioavailable DOC; Heat } \\
\text { island effect; Greater disturbance }\end{array}$ & $\begin{array}{l}\text { The proportion of DIN removed } \\
\text { tends to decline, due to a greater } \\
\text { frequency of flows at high Q (in } \\
\text { stage } 4 \text { ). Restoration that reduces } \\
\text { supply at high flow (detention } \\
\text { ponds) and reconnects riparian } \\
\text { flood plains elevates network scale } \\
\text { nutrient removal }\end{array}$ \\
\hline $\begin{array}{l}\text { Lentic- } \\
\text { dominated } \\
\text { networks }\end{array}$ & $\begin{array}{l}\text { Q: reduced peak flows downstream } \\
\text { C: Fewer extremes in concentration } \\
\text { downstream of lakes due to } \\
\text { transient storage and/or removal by } \\
\text { lakes }\end{array}$ & $\begin{array}{l}\mathrm{L} * \mathrm{~W} \text { : Increased surface area } \\
\mathrm{U} \text { : Increased due to more } \\
\text { macrophytes, higher GPP, OM } \\
\text { storage, heterogeneous redox, } \\
\text { microbial activity }\end{array}$ & $\begin{array}{l}\text { The proportion of biogeochemical } \\
\text { inputs to river network that are } \\
\text { removed remains high across flow } \\
\text { conditions, along with lower } \\
\text { frequency of high flow conditions } \\
\text { in larger rivers downstream }\end{array}$ \\
\hline $\begin{array}{l}\text { Intermittent } \\
\text { networks }\end{array}$ & $\begin{array}{l}\text { Q*C: High variability across dry } \\
\text { versus wet phase. Supply during } \\
\text { dry phase very low for wetted areas } \\
\text { that remain }\end{array}$ & $\begin{array}{l}\mathrm{L} * \mathrm{~W} \text { : High variability across dry } \\
\text { versus wet phase } \\
\mathrm{U} \text { : less biological activity upon } \\
\text { drying and source limitation, } \\
\text { recovering on re-wetting }\end{array}$ & $\begin{array}{l}\text { Hysteresis in river network scale } \\
\text { removal versus flow condition, with } \\
\text { removal during rising limb after } \\
\text { drying less than during falling limb. } \\
\text { Larger rivers that did not dry } \\
\text { dominate network function upon } \\
\text { initial rewetting }\end{array}$ \\
\hline
\end{tabular}

Changes in supply and demand expressed through the variables included in Eq. 1

$C$ concentration, $Q$ discharge, $U$ areal process rate, $L$ stream/river channel length, $W$ stream/river width, $L^{*} W$ surface area, including ponded areas

by extremely high flows (when biota is scoured) or extremely low flows (when biota is desiccated), there will be a decline in removal across a range of flow conditions until recovery has occurred (reduced network scale function). Alternatively, we could also hypothesize that following high flow disturbances, fresh organic matter inputs enhance some functions because energy limitations are alleviated, thus increasing constituent removal across flow conditions (enhanced network scale function).

The RNS complements the idea that aquatic systems do geomorphic work and have an effective discharge at which they maximally process constituents (Doyle 2005; Wollheim et al. 2008). The effective discharge approach integrates function over some time period to account for the frequency of flow conditions. It identifies flows at which river networks receive the most material inputs and when they can remove the most inputs (geomorphic work). If flow frequencies shift, the removal work that can be done by river networks will also shift. The RNS can be used to develop hypotheses to assess how specific characteristics of river networks impact downstream regulation of constituent fluxes (Table 3). These hypotheses could potentially be tested with nested sensor networks or other field approaches (Fig. 6).

The emergent dynamics described by the RNS concept have important policy implications. First, the network scale response curves provide an integrated picture of a river networks capacity to regulate downstream fluxes that could serve as a baseline to quantify the impacts of climate change or other 
anthropogenic forcings. Changes in the flow regime, including shifts in frequency of large floods or drought, will directly affect aquatic regulation of downstream fluxes. The effects of extreme events should be placed in the context of river network function across the entire range of flows (Fig. 1). Second, the RNS demonstrates why management of non-point pollution requires a river network scale perspective. Previous research has frequently highlighted the separate importance of small versus larger streams to cumulative watershed function (Alexander et al. 2000, 2007; Peterson et al. 2001). The RNS demonstrates why both contribute to watershed function depending on flow conditions, with small streams critical at low flows, and larger streams and rivers able to buffer to some degree network scale saturation with increasing flows (Fig. 3). Regulation of water quality in only large rivers, as emphasized in both the U.S. and Europe (Alexander 2015; Adler 2015; Bishop et al. 2008) is not sufficient and should emphasize the entire upstream river network. Further, mitigation of nonpoint source pollution could also be prioritized based on where loads enter the river network, and where sufficient aquatic demand already prevents some breakthrough to critical downstream areas (Mineau et al. 2015). Third, the RNS provides a framework by which to evaluate restoration activities. For example, what is the impact of reconnecting floodplains with their river channels on downstream material fluxes assuming different numbers, extent or locations of such reconnection? Similarly, will restoration of headwater streams make a difference across the flow regime? These and other issues can be explored using the RNS as a research and planning tool.

\section{Recommendations}

There are a number of research priorities that would help enhance understanding of network scale function and better test the RNS. First, improved measurement schemes at network scales should be developed to collect information at spatial and temporal scales relevant to supply and demand processes. One approach, as discussed above, is the use of nested observation networks of in situ sensors for more constituents (e.g., LISST Sequoia sensors for TSS: Czuba et al. 2015; SUNA or sCAN for $\mathrm{NO}_{3}$ : Rode et al. 2016; Wetlabs Cycle P for $\mathrm{PO}_{4}$; SIP-CO2 for
$\mathrm{pCO}_{2}$ : Hunt et al. 2017; CDOM sensors for DOC: Wymore et al. 2018) in a greater variety of watersheds. More affordable in situ sensors are becoming available to make this more feasible (e.g. EPA Low-Cost Nutrient Sensor Action Challenge). Sensors should be deployed in headwaters of representative land uses and downstream at their larger basin mouths. Conductivity sensors should always be co-deployed to allow correction for conservative solute transport and dilution (Wollheim et al. 2017), as is typically done in reach-scale studies of constituent reactivity (Stream Solute Workshop 1990). Aggregation to storm event scales is likely needed to allow comparison across spatial scales, as storm events have different time scales in smaller headwaters compared to larger rivers. In larger watersheds, nested networks at multiple hierarchical levels may be needed to account for spatial variability in loading dynamics.

Second, is the need to better understand and quantify the impact of spatial heterogeneity on function within river networks. Obviously, large lakes, reservoirs, and connected floodplains need to be integrated, as well as their reaction rates for different constituents. But also important is the role of more advection influenced lentic waters, including beaver ponds, fluvial wetlands, and small reservoirs. We hypothesize that the range of conditions existing in heterogeneous river networks enhances overall network function by allowing different processes to dominate in different parts of the flow path that could alleviate source limitation (e.g., conditions that alternately favor nitrification and denitrification), thereby increasing network-scale demand. This phenomenon will require linkages among multiple biogeochemical cycles (e.g., carbon, oxygen, nutrient interactions, Schlesinger et al. 2011; Helton et al. 2015) that also account for links between microbial communities and functions. Finally, a greater understanding of process rates across the range of flow conditions and response to disturbances is needed. Many tools developed to study streams and rivers require low flow conditions and are not easily applied at high flows (Ensign and Doyle 2006; Tank et al. 2008). More effort is needed to estimate reaction rates at higher flows, in higher order reaches, and repeatedly so as to better understand the range of variability and the role of ancillary drivers such as concentration, light, temperature, and other factors. 


\section{Conclusions}

The River Network Saturation concept describes the emergent function of entire river networks and the tendency towards saturation with increasing flows across multiple constituent types, including gaseous, dissolved and particulate species. It suggests how and why network scale removal has a tendency to follow a non-linear pattern with increasing flow as a function of both the constituent reaction rates (whether uptake velocity, settling velocity, piston velocity) and the availability of surface area where biogeochemical processes occur. The RNS concept helps to understand the complex interplay between demand and supply associated with flow and loading concentrations that can lead to changing contributions of smaller versus larger streams, and overall role of aquatic systems in regulating fluxes. For some constituents, the concern is what proportion of inputs reach downstream systems. For others, the concern is how much of a constituent is evading from the network. And for others, the concern is how much of a constituent is accumulating within the network. Anthropogenic activities lead to changes in supply, as well as to both direct and indirect changes in demand. To better understand the role of aquatic systems in continental constituent cycles, and better manage aquatic ecosystem function, including receiving waters, understanding the interplay of supply and demand and how these lead to network scale function will be critical.

Acknowledgements This paper is a product of the AGU Chapman Conference on Extreme Climate Events held in San Juan Puerto Rico in January 2017. We would like to thank the USDA (award \# 2016-67019-25280), NSF-EPSCoR (\#1641157), USGS, National CZO office, and the US Forest Service IITF for funding this AGU Chapman conference on Extreme Climate and providing travel funds to the attendees. This research was also supported by National Science Foundation (NSF) Macrosystem Biology (EF-1065286), NSF EPSCoR (EPS-1101245), and NSF LTER to Plum Island Ecosystem (OCE-1238212 and 1637630). Partial funding was provided by the New Hampshire Agricultural Experiment Station, USDA National Institute of Food and Agriculture Hatch Project NH00609, and is Scientific Contribution \#2743. Any use of trade, firm, or product names is for descriptive purposes only and does not imply endorsement by the U.S. Government.

\section{References}

Aber JD, Nadelhoffer KJ, Steudler P, Melillo JM (1989) Nitrogen saturation in northern forest ecosystems: excess nitrogen from fossil fuel combustion may stress the biosphere. Bioscience 39(6):378-386

Adler RW (2015) US Environmental Protection Agency's new waters of the United States Rule: connecting law and science. Freshw Sci 34:1595-1600. https://doi.org/10.1086/ 684002

Alexander LC (2015) Science at the boundaries: scientific support for the Clean Water Rule. Freshw Sci 34:1588-1594. https://doi.org/10.1086/684076

Alexander RB, Smith RA, Schwarz GE (2000) Effect of stream channel size on the delivery of nitrogen to the Gulf of Mexico. Nature 403:758-761

Alexander RB, Boyer EW, Smith RA, Schwarz GE, Moore RB (2007) The role of headwater streams in downstream water quality. J Am Water Resour Assoc 43(1):41-59

Alexander RB, Böhlke JK, Boyer EW, David MB, Harvey JW, Mulholland PJ, Seitzinger SP, Tobias CR, Tonitto C, Wollheim WM (2009) Dynamic modeling of nitrogen losses in river networks unravels the coupled effects of hydrological and biogeochemical processes. Biogeochemistry 93:91-116. https://doi.org/10.1007/s10533-0089274-8

Basu NB, Destouni G, Jawitz JW, Thompson SE, Loukinova NV, Darracq A, Zanardo S, Yaeger M, Sivapalan M, Rinaldo A, Rao PSC (2010) Nutrient loads exported from managed catchments reveal emergent biogeochemical stationarity. Geophys Res Lett 37:L23404. https://doi.org/ 10.1029/2010GL045168

Bernal S, Sabater F (2012) Changes in stream discharge and solute dynamics between hillslope and valley-bottom intermittent streams. Hydrol Earth Syst Sci 16:1595-1605

Bernal S, von Schiller D, Sabater F, Martí E (2013) Hydrological extremes modulate nutrient dynamics in Mediterranean climate streams across different spatial scales. Hydrobiologia 719:31-42

Bishop K, Buffam I, Erlandsson M, Fölster J, Laudon H, Seibert J, Temnerud J (2008) Aqua Incognita: the unknown headwaters. Hydrol Process 22:1239-1242

Botter G, Bertuzzo E, Bellin A, Rinaldo A (2005) On the Lagrangian formulations of reactive solute transport in the hydrologic response. Water Resour Res 41:W04008. https://doi.org/10.1029/2004WR003544

Boyer EW, Alexander RB, Parton WJ, Li CS, Butterbach-Bahl K, Donner SD, Skaggs RW, Del Gross SJ (2006) Modeling denitrification in terrestrial and aquatic ecosystems at regional scales. Ecol Appl 16(6):2123-2142

Cheng N (1997) Simplified settling velocity formula for sediment particles. J Hydraul Eng 123:149-152

Cole JJ, Prairie YT, Caraco NF, McDowell WH, Tranvik LJ, Striegl RG, Duarte CM, Kortelainen P, Downing JA, Middelburg JJ, Melack J (2007) Plumbing the global carbon cycle: integrating inland waters into the terrestrial carbon budget. Ecosystems 10:171-184

Czuba JA, Straub TD, Curran CA, Landers MN, Domanski MM (2015) Comparison of fluvial suspended-sediment concentrations and particle-size distributions measured with 
in-stream laser diffraction and in physical samples. Water Resour Res 51:320-340. https://doi.org/10.1002/ 2014WR015697

Czuba JA, Hansen AT, Foufoula-Georgiou E, Finlay JC (2018) Contextualizing wetlands within a river network to assess nitrate removal and inform watershed management. Water Resour Res 54(2):1312-1337. https://doi.org/10.1002/ 2017WR021859

Dhillon GS, Inamdar S (2014) Storm event patterns of particulate organic carbon (POC) for large storms and differences with dissolved organic carbon (DOC). Biogeochemistry 118:61-81. https://doi.org/10.1007/s10533-013-9905-6

Dodds WK, Lopez AJ, Bowden WB, Gregory S, Grimm NB, Hamilton SK, Hershey AE, Marti E, McDowell WH, Meyer JL, Morrall D, Mulholland PJ, Peterson BJ, Tank JL, Valett HM, Webster JR, Wollheim WM (2002) N uptake as a function of concentration in streams. J N Am Benthol Soc 21:206-220

Doyle MW (2005) Incorporating hydrologic variability into nutrient spiraling. J Geophys Res 110:GO1003. https://doi. org/10.1029/2005jg000015

Drummond J, Davies-Colley RJ, Stott R, Sukais J, Nagels J, Sharp A, Packman A (2015) Microbial transport, retention, and inactivation in streams: a combined experimental and stochastic modeling approach. Environ Sci Technol 49:7825-7833

Ensign SH, Doyle MW (2006) Nutrient spiraling in streams and river networks. J Geophys Res 111:G04009. https://doi. org/10.1029/2005JG000114

Essington TE, Carpenter SR (2001) Nutrient cycling in lakes and streams: insight from a comparative analysis. Ecosystems 3:131-143

Evans C, Davies TD (1998) Causes of concentration/discharge hysteresis and its potential as a tool for analysis of episode hydrochemistry. Water Resour Res 34:129-137

Ferguson R, Church M (2004) A simple universal equation for grain settling velocity. J Sediment Res 74:933-937

Fisher SG, Gray LJ, Grimm NB, Busch DE (1982) Temporal succession in a desert stream ecosystem following flash flooding. Ecol Monogr 52:93-110

Gardner JR, Doyle MW (2018) Sediment-water surface area along rivers: water column versus benthic. Ecosystems. https://doi.org/10.1007/s10021-018-0236-2

Godsey SE, Kirchner JW, Clow DW (2009) Concentrationdischarge relationships reflect chemostatic characteristics of US catchments. Hydrol Process 23(13):1844-1864

Gu C, Hornberger GM, Mills A, Herman JS, Flewelling S (2007) Nitrate reduction in streambed sediments: effects of flow and biogeochemical kinetics. Water Resour Res 43:W12413

Hall RO, Baker MA, Arp CD, Koch BJ (2009a) Hydrologic control of nitrogen removal, storage and export in a mountain stream. Limnol Oceanogr 54:2128-2142. https:// doi.org/10.4319/1o.2009.54.6.2128

Hall RO, Tank JL, Sobota DJ, Mulholland PJ, O’Brien JM, Dodds WK, Webster JR, Valett HM, Poole GC, Peterson BJ, Meyer JL, McDowell WH, Johnson SL, Hamilton SK, Grimm NB, Gregory SV, Dahm CN, Cooper LW, Ashkenas LR, Thomas SM, Sheibley RW, Potter JD, Niederlehner BR, Johnson LT, Helton AM, Crenshaw CM, Burgin AJ, Bernot MJ, Beaulieu JJ, Arango CP (2009b) Nitrate removal in stream ecosystems measured by $(15) \mathrm{N}$ addition experiments: total uptake. Limnol Oceanogr 54(3):653-665

Hansen AT, Dolph CL, Foufoula-Georgiou E, Finlay JC (2018) Contribution of wetlands to nitrate removal at the watershed scale. Nat Geosci 11:127-132. https://doi.org/10. 1038/s41561-017-0056-6

Helton AM, Poole GC, Meyer JL et al (2011) Thinking outside the channel: modeling nitrogen cycling in networked river ecosystems. Front Ecol Environ 9(229-238):229-238. https://doi.org/10.1890/080211

Helton AM, Ardon M, Bernhardt ES (2015) Thermodynamic constraints on the utility of ecological stoichiometry for explaining global biogeochemical patterns. Ecol Lett 18:1049-1056

Helton AM, Hall RO, Bertuzzo E (2017) How network structure can affect nitrogen removal by streams. Freshw Biol. https://doi.org/10.1111/fwb.12990

Hensley RT, McLaughlin DL, Cohen MJ, Decker PH (2017) Stream phosphorus dynamics of minimally impacted coastal plain watersheds. Hydrol Process 31(8):1636-1649

Hu Y, Lu YH, Liu C, Shang P, Liu J, Zheng C (2017) Sources and dynamics of dissolved inorganic carbon, nitrogen, and phosphorous in a large agricultural river basin in arid northwestern China. Water 9(6):415. https://doi.org/10. 3390/w9060415

Hunt CW, Snyder L, Salisbury JE et al (2017) SIPCO2: a simple, inexpensive surface water pCO2 sensor. Limnol Oceanogr Methods 15:291-301. https://doi.org/10.1002/lom3.10157

Kirchner JW, Feng X, Neal C (2000) Fractal stream chemistry and its implications for contaminant transport in catchments. Nature 403(6769):524-527

Knighton D (1998) Fluvial forms and processes: a new perspective. Oxford University Press, New York, p 383

Koenig LE, Song C, Wollheim WM et al (2017) Nitrification increases nitrogen export from a tropical river network. Freshw Sci 36:698-712. https://doi.org/10.1086/694906

Koenig LE, Shattuck MD, Snyder LE, Potter JD, McDowell WH (2018) Deconstructing the effects of flow on DOC, nitrate, and major ion interactions using a high-frequency aquatic sensor network. Water Resour Res 53(12):10655-10673

Leopold LB, Maddock T Jr (1953) The hydraulic geometry of stream channels and some physiographic implications. Geol Surv Prof Pap 252:1-56

Lovett G, Goodale C (2011) A new conceptual model of nitrogen saturation based on experimental nitrogen addition to an oak forest. Ecosystems 14:615-631

Marcé R, von Schiller D, Aguilera R, Martí E, Bernal S (2018) Contribution of hydrologic opportunity and biogeochemical reactivity to the variability of nutrient retention in river networks. Glob Biogeochem Cycles. https://doi.org/10. 1002/2017GB005677

Miller MP, Tesoriero AJ, Capel PD, Pellerin BA, Hyer KE, Burns DA (2016) Quantifying watershed-scale groundwater loading and in- stream fate of nitrate using highfrequency water quality data. Water Resour Res 52:330-347. https://doi.org/10.1002/2015WR017753

Mineau MM, Wollheim WM, Stewart RJ (2015) An index to characterize the spatial distribution of land use within watersheds and implications for river network nutrient removal and export. Geophys Res Lett 42:6688-6695. https://doi.org/10.1002/2015GL064965 
Mineau MM, Wollheim WM, Buffam I, Findlay S, Hall R, Hotchkiss E, Koenig L, McDowell W, Parr T (2016) Dissolved organic carbon uptake in streams: a review and assessment of reach-scale measurements. J Geophys Res 121:2019-2029. https://doi.org/10.1002/2015JG003204

Mulholland PJ, Helton AM, Poole GC, Hall RO, Hamilton SK, Peterson BJ, Tank JL, Ashkenas LR, Cooper LW, Dahm CN, Dodds WK, Findlay SE, Gregory SV, Grimm NB, Johnson SL, McDowell WH, Meyer JL, Valett HM, Webster JR, Arango CP, Beaulieu JJ, Bernot MJ, Burgin AJ, Crenshaw CL, Johnson LT, Niederlehner BR, O'Brien JM, Potter JD, Sheibley RW, Sobota DJ, Thomas SM (2008) Stream denitrification across biomes and its response to anthropogenic nitrate loading. Nature 452:202-205. https://doi.org/10.1038/nature06686

Newbold JD, Elwood JW, O'Neill RV, Van Winkle W (1981) Measuring nutrient spiralling in streams. Can J Fish Aquat Sci 38:860-863

O'Brien JM, Dodds WK, Wilson KC, Murdock JN, Eichmiller J (2007) The saturation of $\mathrm{N}$ cycling in Central Plains streams: $15 \mathrm{~N}$ experiments across a broad gradient of nitrate concentrations. Biogeochemistry 84:31-49

Park JH, Nayna OK, Begum MS, Chea E, Hartmann J, Keil RG, Kumar S, Lu X, Ran L, Richey JE, Sarma VSS, Tareq S, Xuan DT, Yu R (2018) Reviews and syntheses: anthropogenic perturbations to carbon fluxes in Asian river systems: concepts, emerging trends, and research challenges. Biogeosciences. https://doi.org/10.5194/bg-2017-549

Pellerin BA, Stauffer BA, Young DA, Sullivan DJ, Bricker SB, Walbridge MR, Clyde GR, Shaw DM (2016) Emerging tools for continuous nutrient monitoring networks: sensors advancing science and water resources protection. JAWRA. https://doi.org/10.1111/1752-1688.12386

Peterson BJ, Wollheim WM, Mulholland PJ, Webster JR, Meyer JL, Tank JL, Marti E, Bowden WB, Valett HM, Hershey AE, McDowell WH, Dodds WK, Hamilton SK, Gregory S, Morrall DD (2001) Control of nitrogen export from watersheds by headwater streams. Science 292:86-90. https://doi.org/10.1126/science.1056874

Raymond PA, Saiers JE (2010) Event controlled DOC export from forested watersheds. Biogeochemistry 100:197-209. https://doi.org/10.1007/s10533-010-9416-7

Raymond PA, Zappa C, Butman D, Bott TL, Potter J, Mulholland PJ, Laursen A, McDowell WH, Newbold JD (2012) Scaling the gas transfer velocity and hydraulic geometry in streams and small rivers. Limnol Oceanogr 2:41-53. https://doi.org/10.1215/21573689-21597669

Raymond PA, Saiers J, Sobzak WV (2016) Hydrological and biogeochemical controls on watershed dissolved organic matter transport: pulse-shunt concept. Ecology 97:5-16

Rinaldo A, Botter G, Bertuzzo E, Uccelli A, Settin T, Marani M (2006) Transport at basin scale: 1. Theoretical framework. Hydrol Earth Syst Sci 10:19-29

Rode M, Wade AJ, Cohen MJ, Hensley RT, Bowes MJ, Kirchner JW, Arhonditsis GB, Jordan P, Kronvang B, Halliday SJ, Skeffington RA, Rozemeijer JC, Aubert AH, Rinke K, Jomaa S (2016) Sensors in the stream: the highfrequency wave of the present. Environ Sci Technol 50:10297-10307. https://doi.org/10.1021/acsest6b02155

Rüegg J, Dodds WK, Daniels MD et al (2016) Baseflow physical characteristics differ at multiple spatial scales in stream networks across diverse biomes. Landsc Ecol 31:119-136. https://doi.org/10.1007/s10980-015-0289-y

Sabater S, Timoner X, Borrego C, Acuña V (2016) Stream biofilm responses to flow intermittency: from cells to ecosystems. Front Environ Sci 4:14. https://doi.org/10. 3389/fenvs.2016.00014

Samal N, Wollheim WM, Zuidema S, Stewart RJ, Mineau MM, Huang T, Wake C, Gardner K, Borsuk M, Mavrommati G, Lutz D, Zhou Z, Glidden S, Huber M (2017) Projections of coupled terrestrial and aquatic ecosystem change relevant to ecosystem service valuation at regional scales. Ecol Soc 22:18. https://doi.org/10.5751/ES-09662-220418

Schlesinger WH, Cole J, Finzi A, Holland EA (2011) Introduction to coupled biogeochemical cycles. Front Ecol Environ 9:5-8. https://doi.org/10.1890/090235

Stewart RJ, Wollheim WM, Gooseff M, Briggs MA, Jacobs JM, Peterson BJ, Hopkinson CS (2011) Separation of river network scale nitrogen removal among main channel and two transient storage compartments. Water Resour Res 47:W00J10. https://doi.org/10.1029/2010WR009896

Stewart RJ, Wollheim WM, Miara A, Vorosmarty CJ, Fekete B, Lammers R, Rosenzweig B (2013) Horizontal cooling towers: riverine ecosystem services and the fate of thermoelectric heat in the contemporary Northeast. Environ Res Lett 8:025010

Stream Solute Workshop (1990) Concepts and methods for assessing solute dynamics in stream ecosystems. J N Am Benthol Soc 9(2):95-119

Tank JL, Rosi-Marshall EJ, Baker MA, Hall RO (2008) Are rivers just big streams? A pulse method to quantifying nitrogen demand in a large river. Ecology 89:2935-2945

Thompson SE, Basu NB, Lascurain J et al (2011) Relative dominance of hydrologic versus biogeochemical factors on solute export across impact gradients. Water Resour Res 47:W00j05. https://doi.org/10.1029/2010wr009605

Uehlinger U (2006) Annual cycle and inter-annual variability of gross primary production and ecosystem respiration in a floodprone river during a 15-year period. Freshw Biol 51:938-950. https://doi.org/10.1111/j.1365-2427.2006. 01551.x

Walling DE (1983) The sediment delivery problem. J Hydrol 65:209-237

Webster JR, Patten BC (1979) Effects of watershed perturbation on stream potassium and calcium dynamics. Ecol Monogr 49(1):51-72

Wollheim WM (2016) From headwaters to rivers to river networks: scaling in stream ecology. In: Jones JB, Stanley EH (eds) Stream ecosystems in a changing environment. Elsevier, Amsterdam, pp 349-388

Wollheim WM, Vorosmarty CJ, Peterson BJ, Seitzinger SP, Hopkinson CS (2006) Relationship between river size and nutrient removal. Geophys Res Lett 33(6):L06410. https:// doi.org/10.1029/2006GL025845

Wollheim WM, Peterson BJ, Vorosmarty CJ, Hopkinson CH, Thomas SA (2008) Dynamics of N removal over annual time scales in a suburban river network. J Geophys Res. https://doi.org/10.1029/2007JG000660

Wollheim WM, Stewart R, Aiken GR, Butler KD, Morse N, Salisbury J (2015) Removal of terrestrial dissolved organic carbon in aquatic ecosystems of a temperate river network. 
Geophys Res Lett 42:6671-6679. https://doi.org/10.1002/ 2015GL064647

Wollheim WM, Mulukutla GK, Cook C, Carey RO (2017)

Aquatic nitrate retention at river network scales across flow conditions determined using nested in situ sensors. Water Resour Res. https://doi.org/10.1002/2017WR020644
Wymore A, Potter J, Rodriguez-Cardona B, McDowell W (2018) Using in situ optical sensors to understand the biogeochemistry of dissolved organic matter across a stream network. Water Resour Res 54:2949-2958. https:// doi.org/10.1002/2017WR022168 